\title{
Exploring Learners' Motivations for Studying From Home
}

Normah Ahmad, Nor Rasimah Abdul Rashid, Nur Anisah Tan Abdullah, Choong Pow Yean, Sarinah Sharif, Noor Hanim Rahmat

To Link this Article: http://dx.doi.org/10.6007/IJARBSS/v12-i1/12151

DOI:10.6007/IJARBSS/v12-i1/12151

Received: 16 November 2021, Revised: 20 December 2021, Accepted: 09 January 2022

Published Online: 29 January 2022

In-Text Citation: (Ahmad et al., 2022)

To Cite this Article: Ahmad, N., Rashid, N. R. A., Abdullah, N. A. T., Yean, C. P., Sharif, S., \& Rahmat, N. H. (2022). Exploring Learners' Motivations for Studying From Home. International Journal of Academic Research in Business and Social Sciences, 12(1), 2210-2243.

\section{Copyright: (c) 2022 The Author(s)}

Published by Human Resource Management Academic Research Society (www.hrmars.com)

This article is published under the Creative Commons Attribution (CC BY 4.0) license. Anyone may reproduce, distribute, translate and create derivative works of this article (for both commercial and non0-commercial purposes), subject to full attribution to the original publication and authors. The full terms of this license may be seen at: http://creativecommons.org/licences/by/4.0/legalcode

Vol. 12, No. 1, 2022, Pg. 2230- 2243

Full Terms \& Conditions of access and use can be found at http://hrmars.com/index.php/pages/detail/publication-ethics 


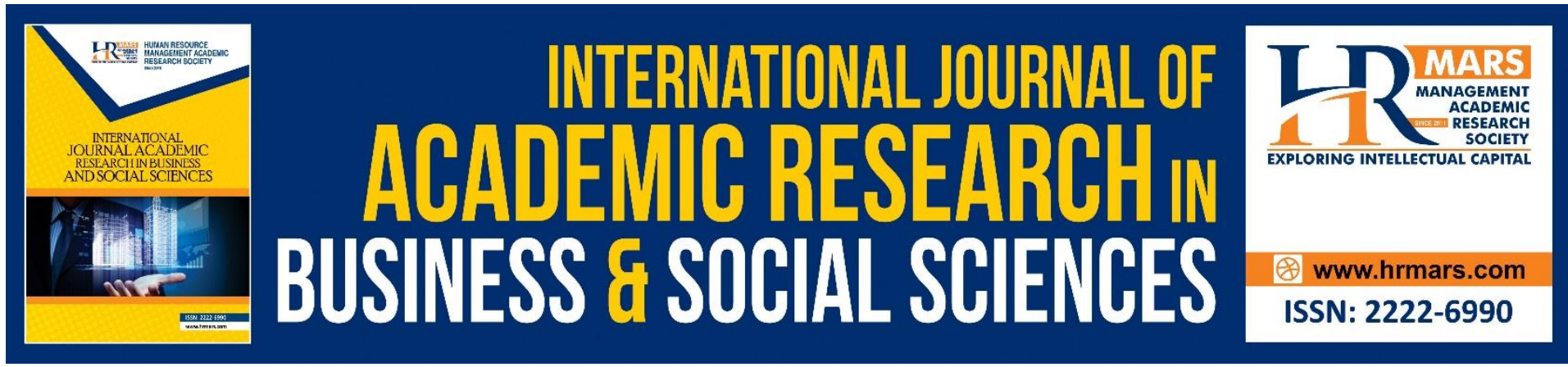

\title{
Exploring Learners' Motivations for Studying From Home
}

\author{
Normah Ahmad', Nor Rasimah Abdul Rashid², Nur Anisah Tan \\ Abdullah ${ }^{3}$, Choong Pow Yean ${ }^{4}$, Sarinah Sharif ${ }^{5}$, Noor Hanim \\ Rahmat $^{6}$ \\ 1,2,3,4 \&5Akademi Pengajian Bahasa Universiti Teknologi MARA Shah Alam \\ ${ }^{6}$ Akademi Pengajian Bahasa Universiti Teknologi MARA Cawangan Johor Kampus Pasir \\ Gudang \\ Email:normah698@uitm.edu.my,nor_rasimah@uitm.edu.my, anistan@uitm.edu.my, \\ choon322@uitm.edu.my,sarinah@uitm.edu.my,noorh763@uitm.edu.my
}

\begin{abstract}
Over the last decade, online learning has grown significantly as the internet and education have merged to provide people with the possibility to learn new skills. Since the COVID-19 outbreak, online learning, or studying at home has become more centric in people's lives. The pandemic has caused schools, universities, and businesses to operate remotely, which has increased the use of online learning. Foreign language learning is also no exception. The purpose of this survey is to find out how students feel about learning from home. This research is based on Alderfer's ERG theory, which proposes three sets of essential needs: existence (E), relatedness (R), and growth (G). A quantitative survey which consists of four sections with 30 items and a 5-point Likert scale was employed. The survey had 109 responses. Findings revealed that learners feel a sense of existence, relatedness, and growth during studying from home. The learners also agreed that the advantages of learning from home outweigh the disadvantages.
\end{abstract}

Keywords: Foreign Language, Online Learning, Motivation, ERG Theory.

\section{Introduction}

Background of Study

Foreign language learning and teaching refer to the teaching or learning of a nonnative language outside of its native environment where it is commonly spoken. In Malaysia, foreign languages are widely taught in schools and universities. Most of the public universities in Malaysia offer the subject of foreign languages. Meanwhile, foreign language learning via online learning actually started long before the Covid-19 pandemic. However, in the past, online learning was used only partially or as a complement to face-to-face learning. At present, due to the pandemic, learning a foreign language has entirely shifted online and become completely compulsory. The term "online learning" refers to the use of a variety of technologies to deliver education over computer networks, including the internet, email, chat, new groups and texts, and audio and video conferencing (Dhull and Sakshi, 2017) 
According to a study conducted at Universiti Teknologi MARA (UiTM) by Allam et al (2020), it was found that internet literacy competency among undergraduate students is at a high level, while self-directed learning and motivation of learning are reported at low levels. Ismail et al (2021) investigated the readiness of online learning in two other Malaysian universities. Among the results obtained were, the readiness of "computer and internet selfefficacy" is the highest, and the lowest score is "learners' control". They concluded that the majority of the respondents are ready for full-scale online learning and had high levels of computer and internet self-efficacy. However, they had less control over their online class since they were easily distracted by other online activities such as messaging, gaming, and surfing the web. To date, no study has been done specifically on the motivation of online foreign language learning at UiTM. Being the largest university in Malaysia, the number of students studying foreign languages is also significant. Thus, it is crucial to investigate UiTM students' perception of online learning or study from home.

\section{Statement of Problem}

Due to Covid-19, most educational institutions in the world have immediately shifted to online learning to ensure learning continues even during the pandemic. When the pandemic hits, students have to bear the most immediate impact of the momentary ending of the traditional face-to-face learning at their institutions. According to research done by Hermanto et al (2021), students' relationship with their family members has a positive impact while they are studying from home. The research shows $87.4 \%$ of the students felt that having plenty of time, meeting, and talking to their family members make the relationship better. This study also proved the family relationship improved as their motivation to study improved. Meanwhile, research done by Alshamrani (2019) highlighted that online learning had eased students' communication. The research shows that students who are shy and nonEnglish speaking in the traditional classroom are able to participate in the online lesson and obtain from the activities of the online learning.

On the contrary, research done by Moise et al (2021) found that in the area of student interaction they found it is difficult to form groups of students that they have not met and known personally for assignments or projects. Some of the extreme measures taken by the students were deferring on the project given and resolving by doing group projects on their own. On the other hand, Onyema et al (2020) reported that to guarantee continuity in teaching and learning, most educators and students depend on technology in online learning. However, inadequate infrastructures such as poor network, poor digital skills, inaccessibility, and unavailability issues, have delayed the process. Hence, this study is done to investigate learners' motivations for studying from home. This investigation is done to answer the following questions;

- How does studying from home gave the learners a sense of Existence?

- How does studying from home gave the learners a sense of Relatedness?

- How does studying from home gave the learners a sense of Growth?

\section{Literature Review \\ Theory of Motivation}

Alderfer's (1969) motivation theory that was initially designed for working conditions can also be understood to understand the motivation of learners. The theory ERG theory suggests that there are three groups of core needs: existence $(E)$, relatedness $(R)$, and growth 
(G). The most basic need is Existence and this relates to the person feeling that what he/she does matters to the people around him/her. Next, is the feeling of Relatedness. This is important because a person needs to feel that whatever that he or she is doing/ asked to do is related to his/her goals. Finally, when the feelings of existence and relatedness are met, then only can the person proceed to Growth.

Advantages of Learning from Home

Studying from home is a great alternative for students who are unable to take real courses or attend physical lessons. There are many advantages of studying from home. According to Mukhtar et al (2020), the advantages of online learning include remote learning, comfort, and accessibility. Online learning stimulates student-centred learning and is easy to control during the lockdown period in the pandemic (Mukhtar et al., 2020). Fatoni et al (2020) state that the advantage of studying from home is that students are able to listen to lessons at any time and place, which leads to a comfortable learning environment as they are not restricted by time and space.

In addition, Risvayeva (2021) acknowledges the benefits of online learning especially in terms of its decreased need in the budget, the accessibility to professional teachers and education institutions across the globe, the convenience and lower costs of using digital resources as opposed to costly physical textbooks and manuals, and finally the objectivity of the assessment of teachers who do not personally know the students.

\section{Disadvantages of Learning from Home}

It has been two years now since the pandemic struck the world, and since then, students have had to study from home. However, although statements say that learning from home has its advantages, some studies show the opposite. Sadeghi (2019) found few disadvantages to learning from home. Learners may have been distracted from their studies. Furthermore, not all learners are IT savvy, and some may face complications in handling technology. During learning from home, there will be less social interaction between learners and lecturers or between peers. This issue may lead to learners' difficulties staying connected with peers or lecturers. Lastly, learners might not be marketable after graduation. According to Serhan (2020), students are negative with this remote instruction when learning from home. They argue that the learning process harms their learning experience and motivation.

Arora \& Shinivasan (2020) also found that teachers who must conduct classes virtually found disadvantages. They claimed that learners' attendance declined. Teachers felt a lack of personal touch during the learning process. Communication between teachers and learners was lacking due to connectivity issues. These were the significant drawbacks of virtual classes. Hebebci et al (2020) also state that teachers and students found disadvantages in distance education. Teachers complained about a lack of interaction and insufficient time during classes. Teachers also found that it was difficult for students to follow up. In addition, there were restrictions and infrastructure problems too. On the other hand, students also found similar challenges. They have interaction and productivity issues. On top of that, they too have infrastructure and technical problems during classes. They found that there was no equality of opportunity too. 


\section{Past Studies on Motivation to Learn}

Motivation is the drive that propels people toward their objectives. Intrinsic and extrinsic motivation are two types of motivation. Some children seem to be driven by their grades, while others seem to be motivated by their parents. When a student's motivation is uncertain, it might be difficult to keep him or her on track. Much research has been conducted to look at the process of acquiring a foreign language. Abdelrahim (2012) looked at the motivation of students at the Islamic University of Sudan to learn English. The sample was chosen at random from a group of $\mathbf{4 0}$ male students studying English at the Faculty of Arts. A questionnaire was utilised as a tool. The findings demonstrated that students had greater motivation levels, with no significant changes in motivation ascribed to class level. Furthermore, there was no connection between motivation and age. At the School of Medicine, College of Medicine, Taipei, Wang et al (2021) investigated pre-clinical medical students' learning motivation toward ultrasonography education. An online open-ended item questionnaire was employed in the research, which included 140 pre-clinical medical students. Students' motives for ultrasonography education were imbalanced among the three ERG categories, according to the findings. Students indicated existence and development motivation more often than relatedness motivation in pairwise comparisons. Existence motivation and development motivation, on the other hand, did not vary much.

Past Studies on Learning from Home

Many studies have been done to investigate the learning of foreign languages online especially after the Covid-19 pandemic hit the world. In 2020, within a short period, schools and universities had to decide to shift all teaching and learning online. Many questions about the efficiency of online teaching, as well as its effects on teachers and students, arose in this climate of uncertainty. These questions led to the production of studies in related matters such as student perception, anxiety, attitude, and motivation during online learning.

Klimova (2021) conducted a study on students' perception and attitude towards online foreign language learning in the Covid-19 pandemic at a university in the Czech Republic. The survey consisted of 10 open questions and was distributed to EFL learners. The findings revealed that students do not believe they have improved their language skills by studying purely online, based on five constructs/variables: language skills, learning materials, students' motivation to study online, preparedness for online teaching and learning, and effectiveness of foreign online teaching. Even though the results show that students find online language education to be effective, the students believe that face-to-face classes cannot be replaced.

Meşe et al (2021) conducted a qualitative case study to explore students' perceptions of online teaching and how it affects their motivation in a seven-week EFL (English as a Foreign Language) course. The results demonstrated that two significant themes emerged, namely the impact of internal and external forces. The qualitative findings show that participants' attitudes toward online education are overwhelmingly negative. Students believe online education harms their motivation due to a lack of social connection, a mismatch between expectations and content, organizational issues, and the organization of learning settings. Pedagogical consequences are stated as a result of several causes, one of which is a lack of engagement with their teachers and classmates. Both studies above suggest that had that there is no covid threat, the students would prefer to have face-to-face classes. 
Conceptual Framework of the Study

This study is rooted in the motivation theory by Alderfer (1969) and work from home variables from Abdullah, et al. (2020). Figure 2 shows the framework for 'studying from home motivation'. In the context of learning from home, learners get to feel the existence through the flexibility of the learning mode. Next, learners feel a sense of relatedness through their study-life balance. Finally, the learners' growth is therefore portrayed through his/her learning performance.

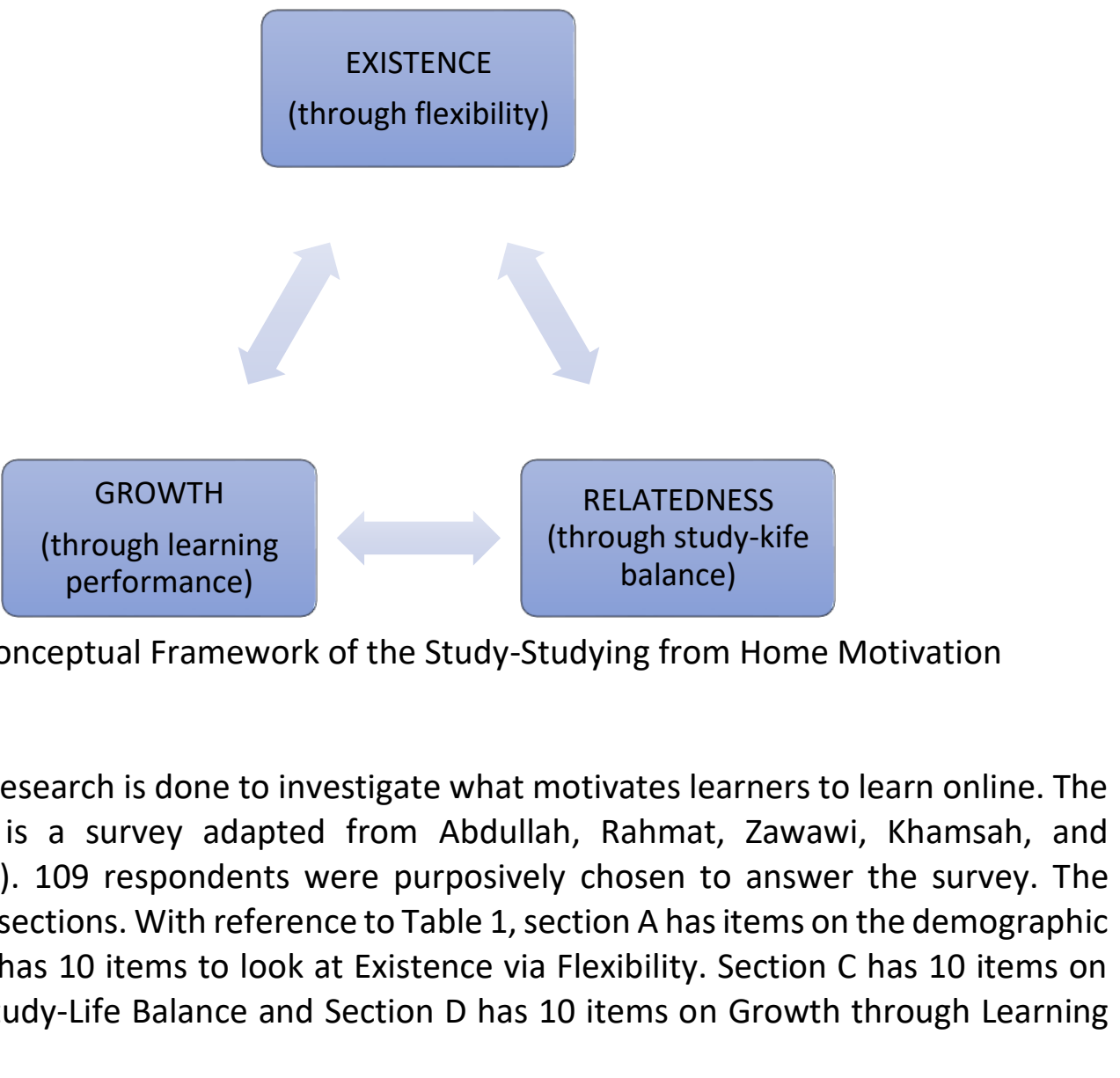

\section{Methodology}

This quantitative research is done to investigate what motivates learners to learn online. The instrument used is a survey adapted from Abdullah, Rahmat, Zawawi, Khamsah, and Anuarsham (2020). 109 respondents were purposively chosen to answer the survey. The survey has 3 main sections. With reference to Table 1 , section $A$ has items on the demographic profile. Section B has 10 items to look at Existence via Flexibility. Section C has 10 items on Relatedness via Study-Life Balance and Section D has 10 items on Growth through Learning Performance.

\begin{tabular}{|l|l|l|l|l|}
\hline SECTION & $\begin{array}{l}\text { ERG Theory of } \\
\text { Motivation }\end{array}$ & STUDYING FROM HOME & $\begin{array}{l}\text { No of } \\
\text { Items }\end{array}$ \\
\hline B & Existence & Flexibility & 10 \\
\hline C & Relatedness & Study-Life Balance & 10 \\
\hline D & Growth & Learning Performance & 10 \\
\hline
\end{tabular}

Table 1: Distribution of Items in the Survey 


\section{Reliability Statistics}

\begin{tabular}{r|r}
$\begin{array}{c}\text { Cronbach's } \\
\text { Alpha }\end{array}$ & N of Items \\
\hline .909 & 30 \\
\hline
\end{tabular}

Table 2: Reliability Statistics for the Instrument

Table 2 presents the reliability statistics for the instrument. SPSS analysis revealed a Cronbach alpha of .909 thus showing high internal reliability of the instrument used. Data is collected online via Google Form. Data is then analysed using SPSS version 26. Analysed data is presented in the form of percentages and mean scores to answer the 2 research questions.

\section{Findings}

Findings for Demographic Profile

Section $A$ is the demographic information consisting of the 109 respondents' (a) gender, (b) year of study, and (c) cluster. The data collected from section $A$ of the survey are as shown below.

(a) Gender

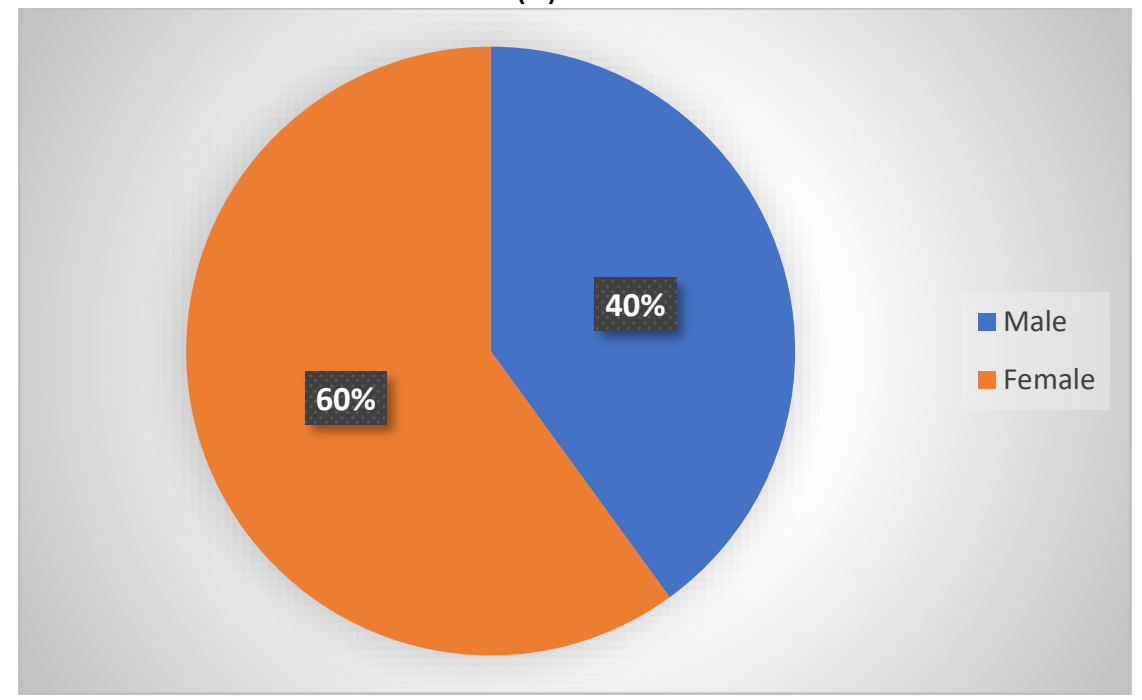

Figure 2: Percentage for Gender

Based on figure 2 above, the analysis on gender shows $62 \%$ of the respondents were female and $40 \%$ were male. 
(b) Year of Study

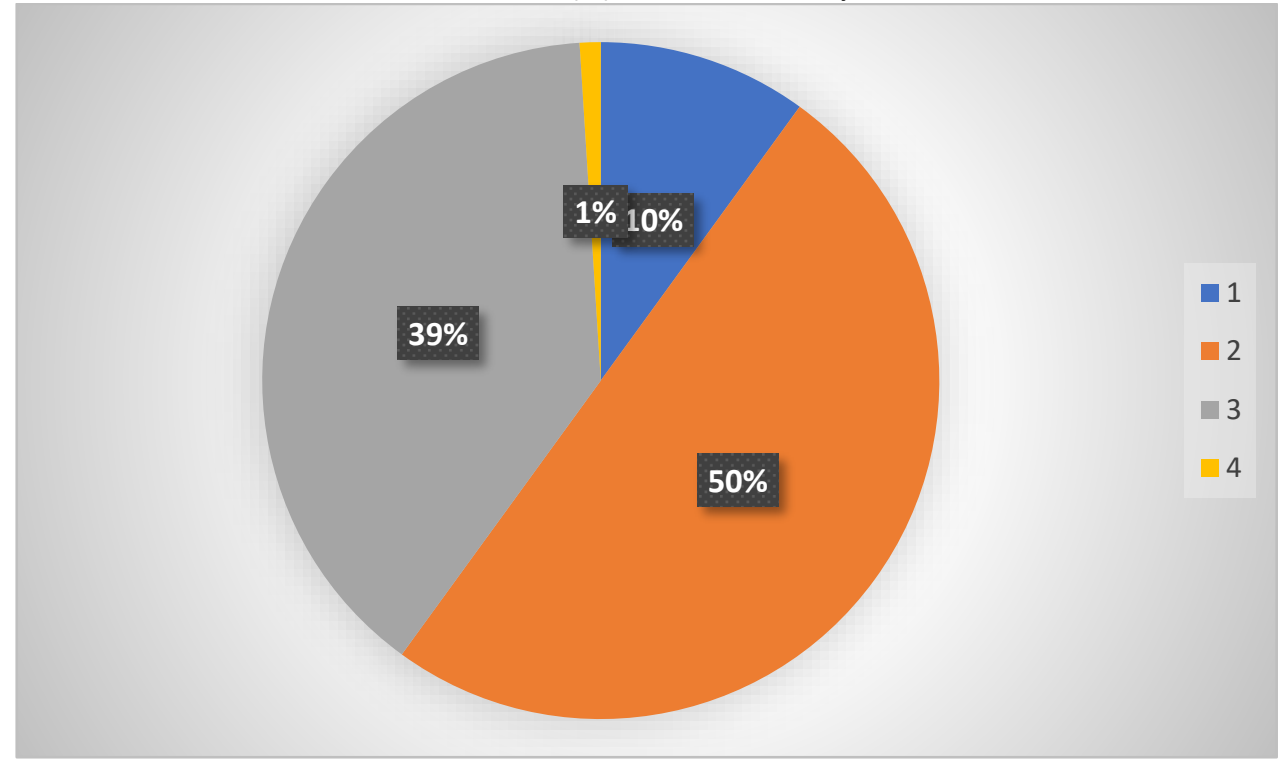

Figure 3: Percentage for Year of Study

Figure 3 above shows the distribution by year of study. 50\% of the respondents were from year 2 . While $39 \%$ were from year $3.10 \%$ of the students were from year 1 and $1 \%$ were from year 4.

(c) Cluster

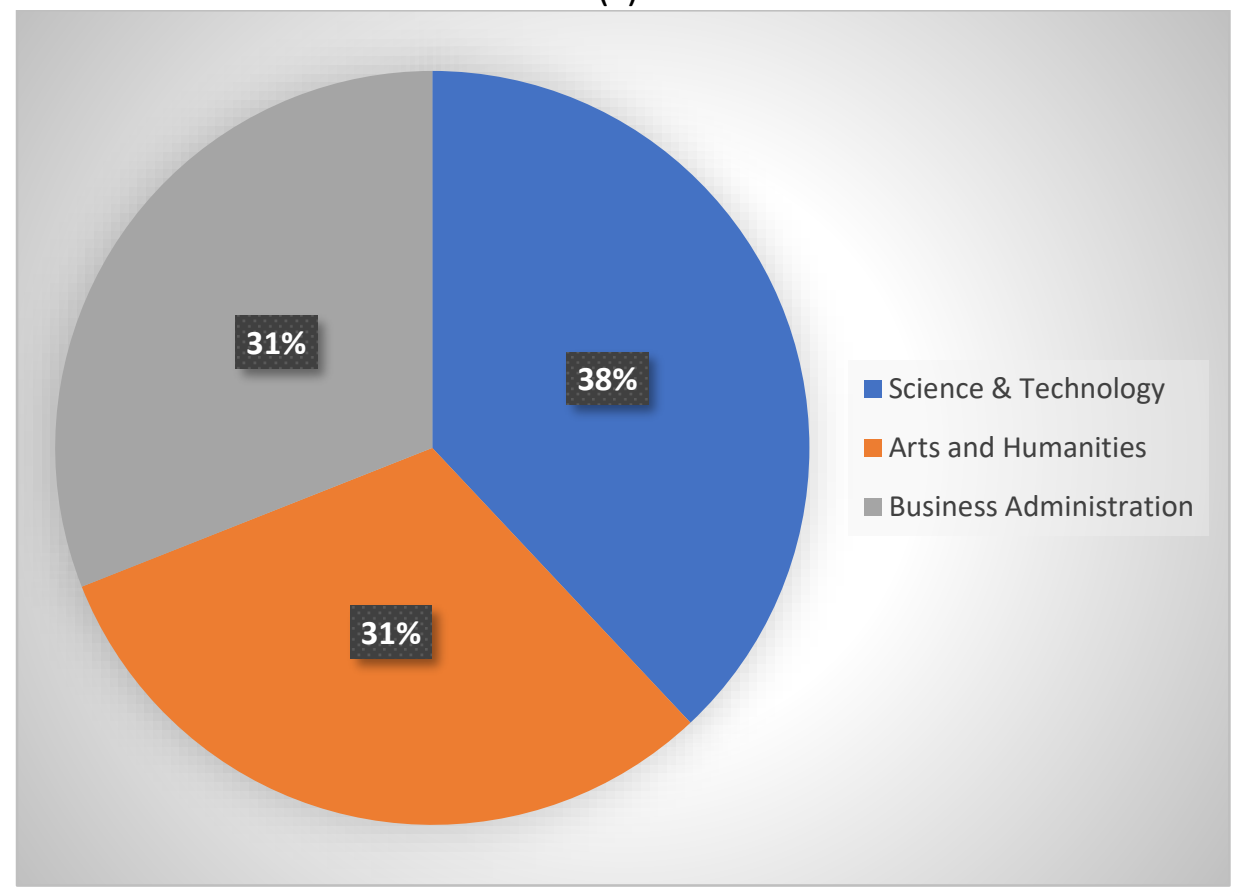

Figure 4: Cluster

Figure 4 shows the distribution by cluster. It shows that $38 \%$ of the respondents were from the cluster of Science and Technology, while 31\% were from the Arts and Humanities and Business Administration. 
Findings for Existence (through Flexibility)

This section presents findings to answer research question 1: How does studying from home gave the learners a sense of Existence? In order to feel a sense of existence, learners who study from their homes enjoyed the flexibility.

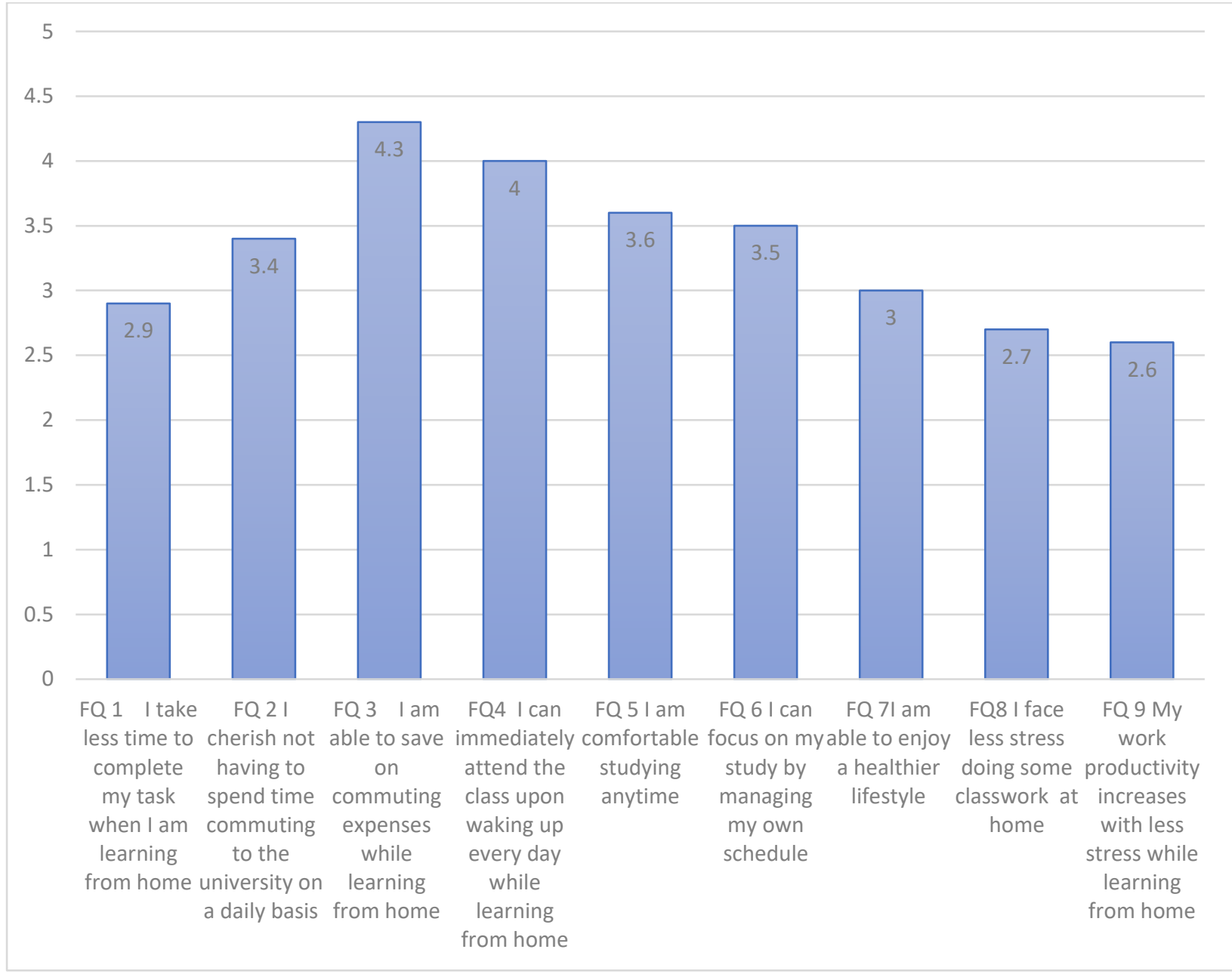

Figure 5: Mean Score for Flexibility

Learning from home has many advantages, as Sadeghi (2019) has mentioned. Flexibilities, cost, and time savings are among some of them. Figure 5 above shows that most learners feel motivated as they can save time commuting to university with a 4.3 mean score, and they can immediately attend classes if they are learning from home with a mean score of 4. The mean scores of 3.6 and 3.5 show that the students are also comfortable learning from home because they can study at any time and manage their schedules. On the other hand, unfortunately, with a mean score of 2.9 and 2.6, learners do not find that learning from home lessens their stress and increases productivity. They take more time to complete their assignments.

Findings for Relatedness (through Learning-work balance)

This section answers research question 2: How does studying from home gave the learners a sense of Relatedness? In order to feel a sense of relatedness, learners need to get a study-life balance. 


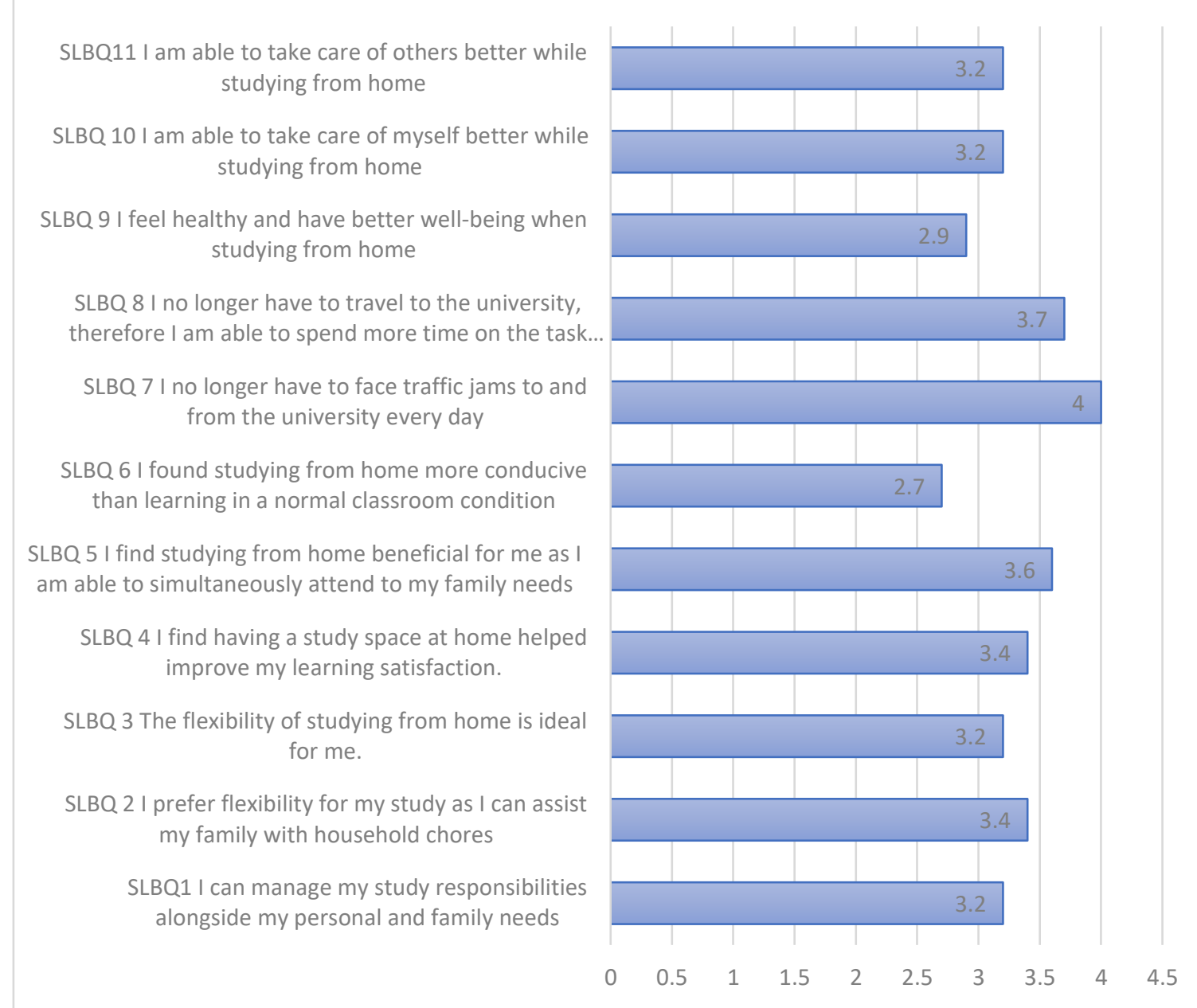

Figure 6-: Mean Score for Study-Life Balance

As shown in figure 6 above, learners feel a sense of relatedness through their studylife balance (Alderfer,1969; Abdullah, et al., 2020). Figure 6 presents the mean scores for study-life balance. The highest mean score is 4.0 which shows that the students feel relieved as they do not need to face traffic jams to or from the university every day. The second highest mean score is 3.7 which indicates that students are able to spend more time on the task at hand as they do not need to travel to their university. Students find studying from home beneficial for them as they are able to simultaneously attend to their family needs alongside their studies (Mean score 3.6). The two statements with the same mean score of 3.4 were respectively the flexibility that allows students to study and assist with household chores at the same time, and also a study space at home that has improved their study satisfaction. Students now have the time and energy to take care of themselves and those around them better (3.2 mean score). It can also be inferred from other statements with the mean score of 3.2 that students appreciate the flexibility which has allowed them to manage their study and personal obligations better. However, students also found that studying from home was not as conducive as studying in a regular physical classroom setting (mean score 2.7).

Findings for Growth (through Learning Performance)

This section presents data to answer research question 3: How does studying from home gave the learners a sense of Growth? Growth can be achieved through increasing learning performance. 


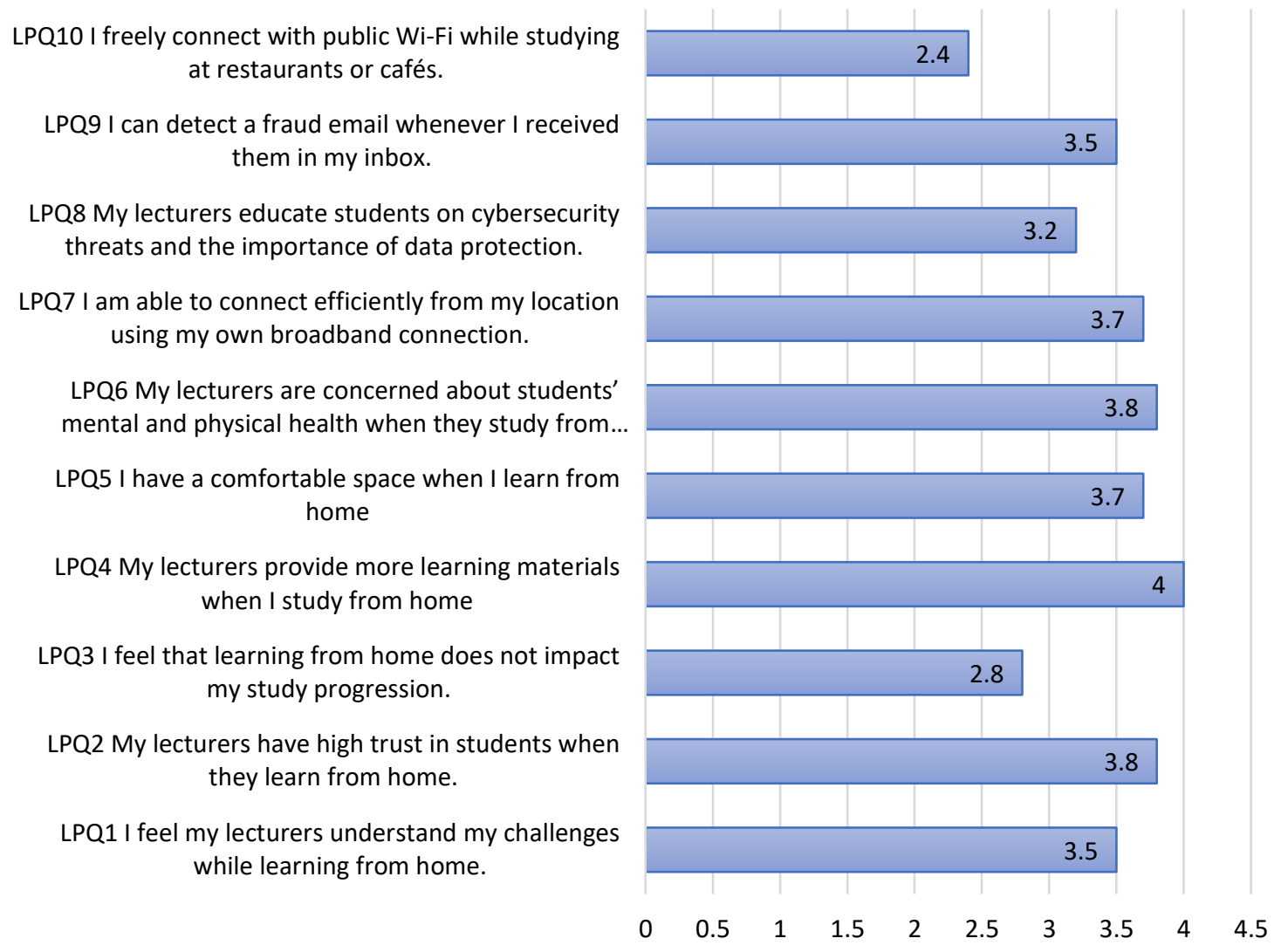

Figure 7: Mean Score for Learning Performance

The results of learning performance are shown in figure 7 . The students agree that the lecturers should give additional learning materials, as shown by the highest mean score (4). Students also claim that their lecturers had a high level of trust in them and that they were concerned about their mental and physical well-being while studying from home (3.8). Students also admit that they have comfortable space when learning from home, and are able to connect efficiently from their location using their own broadband connection (3.7). However, the students confess that while studying in restaurants or cafés, they are not freely connected with public Wi-Fi. This is shown by the lowest mean score (2.4).

\section{Conclusion}

Summary of Findings and Discussions

According to the theory of motivation by Alderfer (1969), it is assumed that a human being has three core needs that he strives to meet. Obtaining his material necessities, sustaining his interpersonal relationships with significant others, and exploring possibilities for his distinctive personal development and evolution are among them. In the current study, learning from home gives the learners a sense of Existence through the flexibility of learning from home. Alderfer (1969) states that existence needs include all the various forms of material and physiological desires. The students in this study seem to appreciate the flexibility of learning from home. For instance, they found that learning at home can save on commuting expenses and time as they don't have to commute to school. However, learning from home does not give them less stress while learning and doing schoolwork at home. In terms of Relatedness, which can be seen through learning-work balance, it shows that the students have more balance in terms of their relationships with other family members. They can attend 
to the family needs and can take care of themselves and others while studying at home. According to Alderfer (1969), relatedness needs include all the needs which involve relationships with significant other people. Meanwhile, Growth here is looked at through learning performance. Growth needs include all the needs which involve a person making creative or productive effects on himself and the environment. The results of this study demonstrate that the students feel comfortable learning from home where they have good connections with lecturers and also a good internet connection. They also receive more materials and adequate attention needed from the lecturers.

In this study, it can be concluded that students perceived studying from home as comfortable, time and cost-saving, and flexible in terms of time and location. However, in terms of stress and productivity, they do not feel that they face less stress studying at home and increasing their productivity.

\section{Pedagogical Implications}

Learning from home is unavoidable due to the pandemic, and it is expected to continue for some time until the pandemic is over. Even if the pandemic is over, many new norms including learning from home are expected to persist. Online learning has become commonplace among today's students. From the current study, it can be seen that students have begun to embrace the fact that learning from home is inevitable and they began to make adjustments to fit into the environment. However, there are things to be improved. The most obvious one is that internet facilities should be improved. A high-speed and reliable internet connection is vital in the current situation. It provides numerous advantages and allows students to fully participate in class and complete their schoolwork on time. In addition, teachers' duties have been proven to be significant as well, and their roles are irreplaceable. Therefore, teachers should adapt their teaching approaches to meet the needs of their students. Teachers also need to equip themselves with new technologies and new knowledge, not only to adapt to the new environment but also to remain relevant.

\section{Suggestions for Future Research}

In the current study, overall students admit that they feel comfortable studying at home, in terms of flexibility, life-work balance, and learning performance. However, at the same time, they also feel stressed performing classwork at home, and they do not find that their productivity increases as their stress levels decrease. There is no clear correlation between being comfortable learning from home and the stress faced by the students. Many possibilities lead to the stress suffered by the students, such as less social interaction between learners and lecturers as well as with peers. Sadeghi (2019) identified certain downsides of learning from home, including fewer social connections. Human beings are social creatures. The lack of social interactions and social relationships are said to have detrimental effects on an individual's physical and psychological health. As a result, future research should focus on why students feel stressed while professing to be comfortable while learning from home. Future research should also look into whether a lack of social interactions can cause major issues. These kinds of research findings are likely to aid students in reducing their stress levels, and also gather some suggestions on improving the idea of learning from home. 


\section{Reference}

Abdelrahim, I. (2012). Motivation to Learn Among English Language Learners in Sudan. Journal of Psychology \& Psychotherapy, Vol 1(4).pp 1-8, Retrieved from https://doi.org/10.4172/scientificreports.237

Abdullah, N. A. A., Rahmat, N. H., Zawawi, F. Z., Khamsah, M. A. N., and Anuarsham, A. H. (2020) Coping with Post COVID-19: Can Work from Home a New Norm? European Journal of Social Science Studies, Vol 5(6), pp 61-81. Retrieved from https://oapub.org/soc/index.php/EJSSS/article/view/933

Aldefer, C. P. (1969) AN Empirical Test of a New Theory of Human needs. Organizational behaviour and Human Performance, Vol 4(2), pp142-175. Retrieved from https://doi.org/10.1016/0030-5073(69)90004-X

Arora, A. K., \& Srinivasan, R. (2020). Impact of Pandemic Covid-19 on the Teaching-Learning Process: A Study of Higher Education Teachers. Prabandhan: Indian Journal of Management, Vol. 13, Issue 4. Retrieved from https://dx.doi.org/: 10.17010/pijom/2020/v13i4/151825

Alshamrani, M. S. (2019). An Investigation of the Advantages and Disadvantages of Online Education. Auckland University of Technology. Unpublished Masters Thesis. Retrieved from http://orapp.aut.ac.nz

Dhull, I., Sakshi, A. (2017). Online Learning. International Education \& Research Journal. Vol 3 (8). Pp 32-34. Retrieved from http://ierj.in/journal/index.php/ierj/article/view/1273

Hebebci, M. T., Bertiz, Y., \& Alan, S. (2020). Investigation of views of students and teachers on distance education practices during the Coronavirus (COVID-19) Pandemic. International Journal of Technology in Education and Science (IJTES), 4(4), 267-282. Retrieved from: https://doi.org/10.46328/ijtes.v4i4.113

Hermanto, Rai, N. G. M., Fahmi, A. (2021). Students' opinions about studying from home during the COVID-19 pandemic in Indonesia. Cypriot Journal of Educational Science. 16(2), 499-510. https://doi.org/10.18844/cjes.v16i2.5627

Ismail, M. H., Saaludin, N., Ali, M. S. N., and Abidin, Z. I. S. (2021). The Foreign Language Students' Readiness on Online Learning in Malaysia. Asia Proceedings of Social Sciences (APSS). Vol 8 (2), pp 11-155. Retrieved from https://readersinsight.net/APSS/article/view/1909

Klimova, B. (2021). Klimova B. An Insight into Online Foreign Language Learning and Teaching in the Era of COVID-19 Pandemic. Procedia Comput Science. 192:1787-1794. http://dx.doi.org/10.1016/j.procs.2021.08.183.

Meşe, E., \& Sevilen, Ç. (2021). Factors influencing EFL students' motivation in online learning: A qualitative case study. Journal of Educational Technology \& Online Learning, 4(1), 11-22. http://doi.org/10.31681/ jetol.817680

Moisei, D. M., Diaconu, A., Negescu, M. D. O., Gombos, C. C. (2021) Online Education During Pandemic Times: Advantages and Disadvantages. European Journal of Sustainable Development (2021), 10, 4, 63-71. Retrieved from http;//dx.doi.org/10.14207/ejsd.2021.v10n4p63

Mukhtar, K., Javed, K., Arooj, M., Sethi, A. (2020). Advantages, Limitations and Recommendations for online learning during COVID-19 pandemic era.2020;36(COVID19-S4):COVID19-S27-S31. https://doi.org/10.12669/pjms.36.COVID19-S4.2785 
Onyema, E. D., Eucheria, N. C., Obafemi, F. A., Sena, S., Atonye, E. G., Sharma, A., Alsayed, O. (2020). Impact of Coronavirus Pandemic on Education. Journal of Education and Practice. Vol 11, No 13, 2020, pp108- 121. www.iiste.org

Rivayeva, C. Z. Q. (2021). Advantages and Disadvantages of Distance Teaching Language. Innovative Technologies in Teaching Foreign Languages and Learner Assessment in Online Education. Vol.2. CSPI Conference 2.2021. Retrieved from https://cyberleninka.ru/article/n/advantages-and-distadvantaged-of-distanceteaching-language/viewer

Sadeghi, M. (2019). A Shift from Classroom to Distance Learning: Advantage and Limitations. International Journal of Research in English Education (IJREE), Vol. 4, Issue 1 (3-2019), pp 80-88. Retrieved from DOI: 10.29252/ijree.4.1.80

Serhan, D. (2020). Transitioning from face-to-face to remote learning: Students' attitudes and perceptions of using Zoom during COVID-19 pandemic. International Journal of Technology in Education and Science (IJTES), 4(4), 335-342. Retrieved from https://doi.org/10.46328/ijtes.v4i4.148

Wang, T. C., Chen, W. T., Kang, Y. N., Lin, C. W., Cheng, C. Y., Suk, F. M., Chen, H. Y., Hsu, C. W., Fong, T. H., \& Huang, W. C. (2021). Why do pre-clinical medical students learn ultrasound? Exploring learning motivation through ERG theory (Vol. 21, Issue 1). https://doi.org/10.1186/s12909-021-02869-4 